\title{
Efficacy of Innovative Technological Approach Ensuring Quality Assurance in Teaching Learning Process in Open and Distance Learning
}

\author{
Cittoor Girija Navaneedhan, T. J. Kamalanabhan \\ Indian Institute of Technology, Madras, Chennai, India \\ Email: girija60@rediffmail.com
}

Received 21 November 2015; accepted 6 December 2015; published 11 December 2015

Copyright (C) 2015 by authors and OALib.

This work is licensed under the Creative Commons Attribution International License (CC BY). http://creativecommons.org/licenses/by/4.0/

(c) (†) Open Access

\section{Abstract}

The present study discusses innovative approach ensuring quality assurance taking into account two important aspects namely: pedagogy and evaluation strategies integrating the effective use of technology. Open and distance learning system plays a key role in enhancing the enrollment ratio in higher education. Therefore, sustaining quality assurance is essentially pivotal in the current digital era. Considering these issues, the paper work illustrates one of the effective ways of evaluation strategies. The study is focused on the undergraduate teacher education program (B. Ed) offered mostly through open and distance education in India. As this course attracts students from urban, rural, with or without technology acquaintance, it should be assessed with transparency by the effective use of technology. The teaching and evaluation procedure used for the students enrolled for the B. Ed degree course includes group discussions integrating brain storming sessions followed by on line tests during their contact classes conducted in the university affiliated institutions. During the evaluation the student's identification should be made authentic by installing software program which detects malpractice. For e.g. if a student logs in to take up online test his/her identification could be detected by the verification of pre-installed photograph. This strategy works out effectively by having proper co-ordination between the Host University and affiliated institution. Maintaining student's authenticity strategy suggested in the present study prevents malpractices during evaluation and enhances student's involvement as it provides transparency without any bias developing faith amongst students enrolled in distance learning.

\section{Keywords}

Evaluation Strategies, Pedagogy, Technology, Enrollment and Distance Education

Subject Areas: Education

How to cite this paper: Navaneedhan, C.G. and Kamalanabhan, T.J. (2015) Efficacy of Innovative Technological Approach Ensuring Quality Assurance in Teaching Learning Process in Open and Distance Learning. Open Access Library Journal, 2: e2166. http://dx.doi.org/10.4236/oalib.1102166 


\section{Introduction}

Evaluation strategies are a set of deterministic rules followed to assess an expression under consideration. Evaluation strategies are divided into two groups, strict and non-strict, based on how arguments to an expression are handled. Therefore, it is real challenge to the open and distance education system to follow a specific evaluation strategy. However, it is necessary to emphasize that the basic evaluation strategy involves the model proposed by Kirkpatrick Model (1979).

For any training or instructions given there exist five levels of evaluation. Level 1: is concerned with the measurement of people's immediate attitudes to the training provided. Level 2: is concerned with measuring the learning achieved as a result of the training. Level 3: is concerned with measuring how actual workplace performance has changed as a result of the training. Level 4: is concerned with measuring the extent to which changes in performance have contributed to improved learning results of the more effective achievement of learning objectives. Level 5: is also important, since it provides a financial value to the organization, of having delivered the training. The present work discusses how to sustain quality in adopting recommended evaluation strategy based on the five basic levels of evaluation.

Level 1: is concerned with the measurement of people's immediate attitudes to the training provided. Philosophers like Dennett [1] and Ziman, J. [2] and Popper [3] have all agreed that actions are brought about by beliefs, not just by knowledge alone. Donald Schon [4] suggested "reflection-in-action” would be effective in enhancing the cognitive process as it initiates the feeling “feelings about one's own performance”. This method of evaluating one's own performance was first found by Fox, L. [5] being practiced worldwide in teacher education programme.

Level 2: is concerned with measuring the learning achieved as a result of the training. The second level could be evaluated by encouraging social interaction during the contact programme in the concerned subject. Edwards [6] suggested that encouraging the student participation in brain storming sessions enables them to learn better as it provides a back ground for peer interaction just to reassure them that others are suffering from the same problems as they are.

Level 3: is concerned with measuring how actual workplace performance has changed as a result of the trainingthis could be done by inspecting the actual work performance by senior supervisors giving immediate feedback. The inspection has to be followed up for improving better performance at work place.

Level 4: is concerned with measuring the extent to which changes in performance have contributed to improved learning results of the more effective achievement of learning objectives. At this level it is recommended to introduce compulsory on line objective based test to assess the student learning and checking the authenticity by identifying him through web camera similar to video conferencing or teleconferencing.

Level 5: is also important, since it provides a financial value to the organization, of having delivered the training. At this level it is important to assess practicality of the recommendation of evaluation strategy considering the socio-economic aspect; the present paper recommends setting up of quality control cell monitoring the quality assurance of open and distance learning. The quality assurance cell should comprise of experienced faculty members capable of upgrading the quality of evaluation strategies in a creative manner.

\subsection{Challenges in Implementing Technology Based Evaluation to Sustain Quality}

It is possible to use next-generation wireless technologies promising ubiquitous networking and mobile computing on a large scale with high-bandwidth data service and a wireless Internet as suggested by Fasbender \& Reichert [7], Gibson [8], Negus, Stephens \& Landford [9], and Ojanpera and Prasad [10]. However, there are still numerous challenges such as reliability and quality of service, infrastructure costs, and energy efficiencies. Technology advances have made it conceivable to build and deploy dense wireless networks of heterogeneous nodes collecting and disseminating wide ranges of environmental data , applications of such sensor and monitoring networks include smart warehouses equipped with security, identification, and personalization systems; intelligent assembly systems; warehouse inventory control; interactive learning systems; and disaster mitigation , Alexander, S. \& McKenzie, J [11]. The opportunities emerging from this technology give rise to new paradigm shift in Open and distance learning. Groves, M. \& Zemel, P [12].

\subsection{Sample}

A sample of 100 B. Ed students of 25 males and 75 females in the age group 20 to 35 years with average age 
group 28 years enrolled through open and distance educations were selected for the study. A questionnaire consisting of 25 statements based on the five basic levels of evaluation were formulated to measure the implementation of effective measures to sustain quality assurance were distributed to the students. The scores obtained were subjected to statistical analysis using Microsoft office 365 statistical packages as it only involves the calculation of Pearson product moment correlation coefficient values between the components.

\section{Methodology}

The emergence of the Internet and related networks such as the World Wide Web has had and will increasingly have radical effect on the transformation of education and training in all sectors. The impact is already significant in all developed countries, and the great majority of developing countries are despite difficulties and fears seeking to take part in the emerging global educational community. The present work suggests web based evaluation strategy in open and distance education similar to the instructional design adopted in pedagogy. Teacher quality Teacher quality is an issue in most countries. Many teachers who enroll themselves to get B. Ed degree through open and distance mode lack competency in teaching subjects. In addition, teachers face a widening range of demands and roles. In order to ensure the quality in open and distance mode it is necessary to implement innovative pedagogy of teaching and learning along with effective evaluation strategies. The evaluation strategy recommended in the present work is depicted in the form of a simple model. The model shown in Figure 1 explains how to carry about the evaluation process in open and distance learning in teacher education.

Step I: The teacher trainer should acquire the practical skill through reflective action practiced during contact program.

Step II: Carrying out inspection to know the outcome of reflective action.

Step III: Conducting brain storming sessions in various subjects as mentioned in the syllabus to improve the cognitive process along with improvement in the societal interaction among the students proving a positive learning environment.

Step IV: Online objective based test to be conducted for every student in order to curb the possibilities of malpractices occurring during despite all preventive measures taken by the universities.

\subsection{Objectives of the Study}

- To suggest effective evaluation strategy in order to sustain quality in open and distance education integrating technology.

- To find the relationship between the levels of evaluation.

\subsection{Research Hypotheses}

- There is no significant relationship between the levels of evaluation.

- Effective evaluation strategy has no impact in the sustainability of quality in open and distance mode.

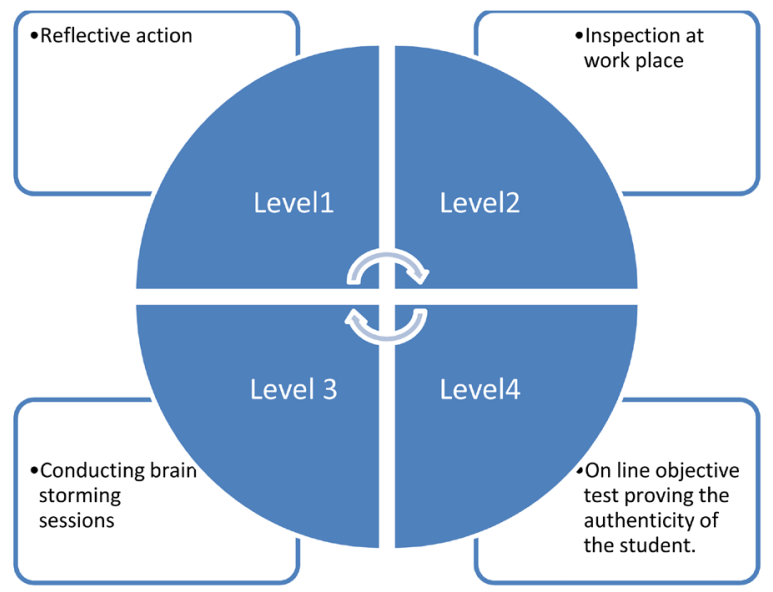

Figure 1. Shows the evaluation strategy model involving the basic four steps. 


\subsection{Statistical Tool}

The focus of the work is to high light the basic levels in evaluation strategy, a questionnaire was prepared by author to measure the effectiveness of the implementation of the four basic levels of evaluation strategy. It consists of 25 statements in four subdivisions a, b, c, and d. Sub division "a" consists of six statements ,sub division "b" consists of seven statements, subdivision "c" consists of six statements, and sub division's" consists of six statements. The evaluation of each statement is based on five point Likert scale a) agree, b) disagree, c) undecided d) totally disagree, and e) strongly agree. The questionnaire was distributed to students enrolled through open and distance learning and were asked to read each and every statement and tick the possible option in accordance to their understanding. The scores were collected and the correlation coefficient values were calculated among the four levels of evaluation.

\subsection{Findings}

From the Table 1 and the Figure 2, it could be stated that female candidates show better relation in reflective action and inspection, reflective action and online test and brain storming and online test compared to their male counterparts. Whereas in reflective action and brain storming as well as in inspection and brain storming male candidates showed better relationship than female counterparts. In the relationship between Inspection and Online test Male and female candidates showed almost equal relationship. It is evident from the findings that those who practice reflective action during the teaching practice do better in online test as well as in brain storming session. Hence female candidates outperformed their male counterparts.

\section{Results and Discussion}

It was found that there was significant relationship between the four levels of evaluation strategies. The third level of evaluation develops social skills through communication and empathy. First levels of evaluation help

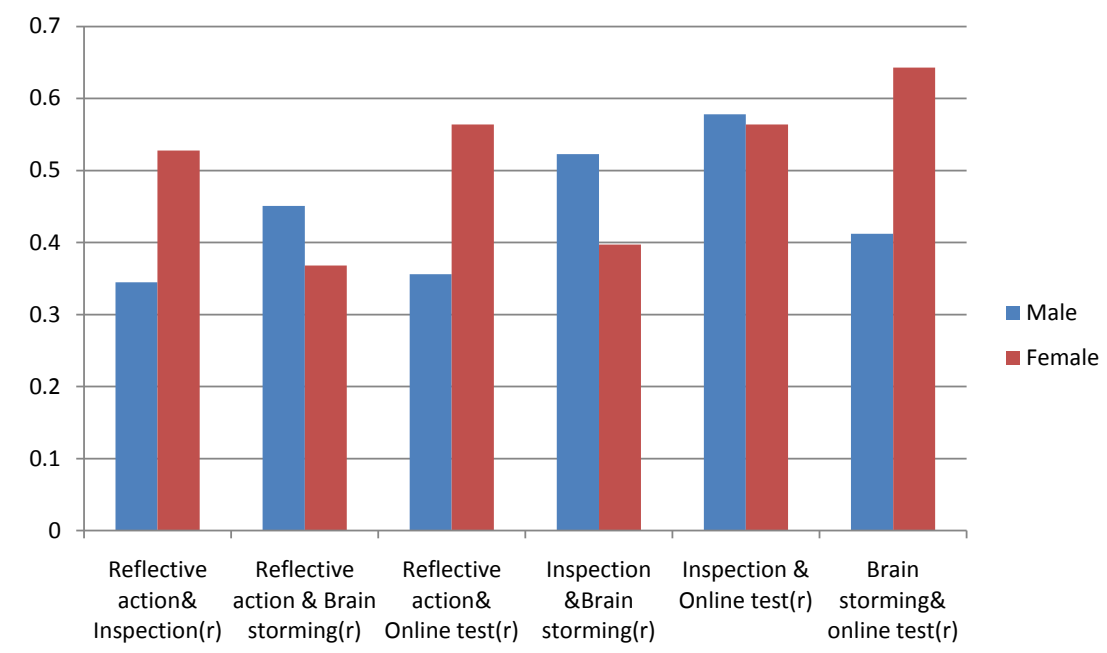

Figure 2. Graphical representation showing the correlation coefficient (r) values between the four levels of evaluation strategy to be practiced in teacher education in distance learning program.

Table 1. To show the interrelation between the various components of evaluation strategy model.

\begin{tabular}{ccccccccc} 
S.No & Sample & Gender & $\begin{array}{c}\text { Reflective } \\
\text { action \& } \\
\text { Inspection }(r)\end{array}$ & $\begin{array}{c}\text { Reflective } \\
\text { action \& Brain } \\
\text { storming (r) }\end{array}$ & $\begin{array}{c}\text { Reflective } \\
\text { action\& } \\
\text { Online test }(r)\end{array}$ & $\begin{array}{c}\text { Inspection \& } \\
\text { Brain storming } \\
(\mathrm{r})\end{array}$ & $\begin{array}{c}\text { Inspection } \\
\text { \& Online } \\
\text { test (r) }\end{array}$ & $\begin{array}{c}\text { Brain } \\
\text { storming \& } \\
\text { online test (r) }\end{array}$ \\
\hline 1 & 25 & Male & $0.345^{*}$ & $0.451^{*}$ & $0.356^{*}$ & $0.523^{*}$ & $0.578^{*}$ & $0.412^{*}$ \\
2 & 75 & Female & $0.528^{*}$ & $0.368^{*}$ & $0.564^{*}$ & $0.397^{*}$ & $0.564^{*}$ & $0.643^{*}$ \\
\hline
\end{tabular}

${ }^{*} P<0.05,{ }^{* *} P: 0.01,{ }^{* * *} P: 0.001$, N.S = Not significant. 
the students to develop solid academic knowledge, which is a prerequisite for effective teaching and learning. The second levels of evaluation provide students with an understanding of how children learn and develop. It covers general didactics, basic teaching and learning methods, the teacher as leader and the social role of schools. The fourth level of evaluation provides Professional teaching realized both through understanding the subject areas and by acquiring insight through actual practice in teaching the subjects.

\section{Conclusions}

In order to assure the quality of the B. Ed study program through open and distance mode the following measures are recommended to be implemented.

\section{The role of the faculty is to:}

$>$ Provide information on course material and academic expectations.

> Provide relevant teaching, supervision and examinations that correspond to the curriculum.

$>$ Use of Class web page as a means of providing supervision and information.

$>$ Use of Web camera in the assessment process.

$>$ Use of objective based test in all the subjects mentioned in the curriculum.

The role of the student is to:

$>$ Organize their time effectively, acquire the necessary course literature and be well prepared for learning activities.

$>$ Complete assignments for the portfolio, keep deadlines, and follow guidelines.

$>$ Cooperate with other students in activities and learning processes.

$>$ Participate in the workshops, as well as the synchronous teaching and asynchronous teaching between the workshops.

$>$ Log into the online classroom in class web page at least twice a week during the academic year.

$>$ Participate in the teaching on the web two to three times a week, 6 - 9 teaching hours during the working day. If the teacher and the students meet their expectations as mentioned in implementation recommendation, it is possible to promote quality assurance in open and distance learning mode.

\section{References}

[1] Dennett, D.C. (1981) Brainstorms: Philosophical Essays on Mind and Psychology. MIT Press, Cambridge.

[2] Ziman, J. (1978) The Research Enterprise in the Soviet Union. Science, 201, 1115-1116. http://dx.doi.org/10.1126/science.201.4361.1115

[3] Popper, K.R. (1972) Objective Knowledge: An Evolutionary Approach. Revised Edition, Oxford University Press, Oxford.

[4] Schon, D. (1983) The Reflective Practitioner: How Professionals Think in Action. Temple Smith, London.

[5] Fox, L. (1994) Preparing Teachers for Inclusive Education: The Development of a Unified Teacher Education Program in Early Childhood and Early Childhood Special Education. Teacher Education in Special Education, 17, 38-51. http://dx.doi.org/10.1177/088840649401700105

[6] Fiske, E. (1996) Department of Education Queensland, Principles of Effective Learning and Teaching. Publishing Services for Studies Directorate: Queensland.

[7] Fasbender, A., Reichert, F., Geulen, E., et al. (1999) Any Network, Any Terminal, Anywhere. IEEE Personal Communication, 6, 22-30.

[8] Gibson, J.D. (1999) The Mobile Communication Handbook. CRC Press, Miami.

[9] Negus, K.J., Stephens, A.P. and Landford, J. (2000) Home RF: Wireless Networking for the Connected Home. IEEE Personal Communication, 7, 20-27. http://dx.doi.org/10.1109/98.824568

[10] Ojanpera, T. and Prasad, R. (1998) An Overview of Third Generation Wireless Personal Communication: A European Perspective. IEEE Personal Communications, 5, 59-65. http://dx.doi.org/10.1109/98.736477

[11] Alexander, S. and McKenzie, J. (1998) An Evaluation of Information Technology Projects for Learning. Committee for University and Staff Development, Canberra.

[12] Groves, M. and Zemel, P. (2000) Instructional Technology Adoption in Higher Education: An Action Research Case Study. International Journal of Instructional Media, 27, 57-65. 